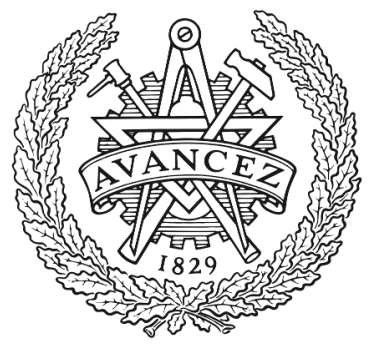

CHALMERS

UNIVERSITY OF TECHNOLOGY

\title{
Microwave-Assisted Synthesis of Co/CoOx Supported on Earth-Abundant Coal-Derived Carbon for Electrocatalysis of Oxygen Evolution
}

Downloaded from: https://research.chalmers.se, 2023-04-26 02:00 UTC

Citation for the original published paper (version of record):

Pan, H., Wu, D., Huang, X. et al (2019). Microwave-Assisted Synthesis of Co/CoOx Supported on Earth-Abundant Coal-Derived Carbon for

Electrocatalysis of Oxygen Evolution. Journal of the Electrochemical Society, 166(8): F479-F486.

http://dx.doi.org/10.1149/2.0281908jes

N.B. When citing this work, cite the original published paper. 


\title{
ECSS \\ Microwave-Assisted Synthesis of $\mathrm{Co} / \mathrm{CoO}_{\mathrm{x}}$ Supported on Earth-Abundant Coal-Derived Carbon for Electrocatalysis of Oxygen Evolution
}

\author{
Haoran Pan,,${ }^{1,}=$ Dongling Wu, ${ }^{2,}=$ Xinning Huang, ${ }^{3}$ Kunpeng Xie,${ }^{4}$ Bingcai He, ${ }^{1}$ Zhenjie Lu, ${ }^{1}$ \\ Penggao Liu, ${ }^{1}$ Junxia Cheng, ${ }^{1}$ Xuefei Zhao, ${ }^{1}$ Justus Masa, $\oplus^{5, z}$ and Xingxing Chen ${ }^{1, z}$ \\ ${ }^{I}$ Research Group of Functional Materials for Electrochemical Energy Conversion, School of Chemical Engineering, \\ University of Science and Technology Liaoning, 114051 Anshan, People's Republic of China \\ ${ }^{2}$ Key Laboratory of Energy Materials Chemistry, Institute of Applied Chemistry, Xinjiang University, 830046 Urumqi, \\ People's Republic of China \\ ${ }^{3}$ Engineering Training Center, University of Science and Technology Liaoning, 114051 Anshan, People's Republic of \\ China \\ ${ }^{4}$ Competence Centre for Catalysis and Chemical Engineering, Chalmers University of Technology, 41296 Gothenburg, \\ Sweden \\ ${ }^{5}$ Analytical Chemistry-Center for Electrochemical Sciences (CES), Ruhr-University Bochum, 44780 Bochum, Germany
}

The evident demand for hydrogen as the ultimate energy fuel for posterity calls for the development of low-cost, efficient and stable electrocatalysts for water splitting. Herein, we report the synthesis of $\mathrm{Co} / \mathrm{CoO}_{\mathrm{x}}$ supported on coal-derived N-doped carbon via a simple microwave-assisted method and demonstrate its application as an efficient catalyst for the oxygen evolution reaction (OER). With the optimal amount of cobalt introduced into the N-doped coal-derived, the developed catalyst achieved overpotentials of 0.370 and $0.429 \mathrm{~V}$ during water oxidation at current densities of $1 \mathrm{~mA} \mathrm{~cm}-2$ and $10 \mathrm{~mA} \mathrm{~cm}^{-2}$, respectively. There was no noticeable loss in the activity of the catalyst during continuous galvanostatic polarization at a current density of $10 \mathrm{~mA} \mathrm{~cm}{ }^{-2}$ for a test period of $66 \mathrm{~h}$. The synergistic interaction of the $\mathrm{Co} / \mathrm{CoO}_{\mathrm{x}}$ moieties with the pyridinic and pyrollic nitrogen functional groups in the $\mathrm{N}$-doped carbon, as well with the other heteroatoms species in the pristine coal favored enhancement of the OER electrocatalytic performance. (c) The Author(s) 2019. Published by ECS. This is an open access article distributed under the terms of the Creative Commons Attribution 4.0 License (CC BY, http://creativecommons.org/licenses/by/4.0/), which permits unrestricted reuse of the work in any medium, provided the original work is properly cited. [DOI: 10.1149/2.0281908jes]

(cc) BY

Manuscript submitted January 11, 2019; revised manuscript received April 4, 2019. Published April 26, 2019.

Renewable energy-driven electrolysis of water to produce hydrogen, the ultimate energy carrier for a green and sustainable energy future, is constrained by inefficient electrocatalysis of the underlying half-cell reactions that operate at rather high reaction overpotentials, thereby rendering the process costly and commercially unattractive compared to other hydrogen production technologies. ${ }^{1}$ Commercial electrolyzers typically operate at a cell voltage of $1.8-2.0 \mathrm{~V}$, which is much higher than the theoretical minimum of $1.23 \mathrm{~V}$. In particular, the overpotential of the oxygen evolution reaction (OER) is considerably very high compared to that of the hydrogen evolution counter reaction and is thus the major obstacle for further improvement of the efficiency of water electrolyzers. ${ }^{2}$ Ir- and Ru-oxides are the present stateof-the art catalysts for the OER, their scarcity and high-prices notwithstanding, which limits any prospects of their application for industrial scale-up. ${ }^{3-5}$ In recent years, non-noble free first-row transition metalsbased materials (such as $\mathrm{Co}, \mathrm{Mn}, \mathrm{Ni}, \mathrm{Fe}, \mathrm{Cu}$ ), have gained noticeable popularity in developing promising low-cost OER catalysts owing to innovations in material design beneficial for enhancement of kinetic phenomena and stabilization of active sites. ${ }^{6-9}$ However, the intrinsically low electronic conductivity of metal oxides and the tendency of their nanoparticles to aggregate into larger clusters thereby negating the beneficial effects of high surface area, hamper optimal utilization of the full potential of these materials as OER electrocatalysts. ${ }^{10} \mathrm{On}$ the other hand, carbon materials such as graphene, carbon nanotubes, carbon black and porous carbon doped with foreign atoms, for example, sulfur, nitrogen and boron have been demonstrated to play an important role as catalysts and catalyst supports for OER. ${ }^{11-14}$ The carbon structures, and their heteroatom-modified derivatives, not only lead to enhanced electron transfer but also minimize agglomeration of the catalyst particles by their embedment within the heteroatom modified carbon matrix thus leading to OER activity enhancement. ${ }^{15-18}$

Coal with an abundant global supply is one of the three most important primary energy resources in the world. However, the direct combustion of coal to generate energy is one of the leading causes of $\mathrm{CO}_{2}$ emissions in the atmosphere, the main precursor for global

\footnotetext{
$=$ These authors contributed equally to this work.

${ }^{\text {z} E-m a i l: ~ j u s t u s . m a s a @ ~ r u b . d e ; ~ x i n g c h e n s t a r 79 @ 163 . c o m ~}$
}

warming. It is therefore vitally important to innovate new possibilities for coal beneficiation to develop value-added products. ${ }^{19-22}$ With the increasing demand and urgency of developing non-noble metal catalysts for OER, pristine coal, which essentially consists of graphene stacking structures and impurity elements such as $\mathrm{H}, \mathrm{O}, \mathrm{N}, \mathrm{S}, \mathrm{Si}$, $\mathrm{Fe}, \mathrm{Mn}$, among others, ${ }^{23-25}$ is seen as a potential material to prepare OER electrocatalyst. Following the reports on the application of different coals as raw materials to produce $\mathrm{N}$-doped porous carbon, which showed good electrocatalytic performance toward oxygen reduction reaction (ORR) in acidic media, ${ }^{26-29}$ our group has also studied the influence of acid pretreatment on the electrocatalytic performance of coal-derived carbon catalysts toward ORR in alkaline media. ${ }^{30} \mathrm{Re}-$ cently, we reported the possibility to directly convert earth-abundant coal into high-performance bifunctional electrocatalysts for both the oxygen evolution and oxygen reduction reactions without any acid pretreatment and additional introduction of metals. ${ }^{31}$ However, further improvement of the electrocatalytic performance of the oxygen reactions, is still a challenge that we have to overcome. To the best of our knowledge, no work has been reported on the preparation of a composite electrocatalyst using coal-derived carbon as support for transitional metals for improved electrocatalysis of the OER.

In this work, we report a facile and simple microwave-assisted method to synthesize $\mathrm{Co} / \mathrm{CoO}_{\mathrm{x}}$ supported on $\mathrm{N}$-doped coal-derived carbon, which efficiently catalyzes the OER under alkaline conditions. The synergistic interaction of $\mathrm{Co} / \mathrm{CoO}_{\mathrm{x}}$ with the pyridinic and pyrollic nitrogen functional groups in the $\mathrm{N}$-doped coal-derived carbon matrix, as well as with the other heteroatom species present in the coal-derived carbon is believed to be the origin for the good OER performance of the catalyst.

\section{Experimental}

Chemicals and solutions. - Brown coal was got from Hailar Coal Mine, Inner Mongolia as a present and its chemical compositions obtained by industrial analysis and elemental analysis have been reported previously. ${ }^{30,31}$ Cobalt acetate* $4 \mathrm{H}_{2} \mathrm{O}(\geq 99.5 \%)$ was bought from Sinopharm Chemical Reagent Co. Ltd. (China). $\mathrm{NaOH}(\geq 96 \%)$ and ethanol $(\geq 99.8 \%)$ were got from Tianjin Rgent Chemicals Co. 
Ltd. (China). Nafion (5\%) was bought from Sigma-Aldrich (China). All aqueous solutions were prepared using tri-distilled deionized water.

Sample preparation.- - The original brown coal was first crushed by ball milling, followed by pretreatment with $\mathrm{HNO}_{3}$ vapor at $200^{\circ} \mathrm{C}$ for $12 \mathrm{~h}$ in order to improve the hydrophilicity of the coal sample. The sample was then thermally treated in a horizontal quartz chemical vapor deposition $(\mathrm{CVD})$ reactor where it was first flushed with nitrogen at a flow rate of $50 \mathrm{~mL} \mathrm{~min}^{-1}$ for $15 \mathrm{~min}$ prior to raising the temperature up to $800,950,1050$ or $1100^{\circ} \mathrm{C}$ at a rate of $10 \mathrm{~K} \mathrm{~min}^{-1}$ in a $100 \mathrm{~mL}$ min $^{-1}$ stream of $\mathrm{NH}_{3}$ and $\mathrm{Ar}$ (1:9 volume ratio) and maintained at this temperature for $2 \mathrm{~h}$. After the reaction, the reactor was cooled down in the same atmosphere with the same flow rate for $5 \mathrm{~h}$ and finally switched to nitrogen with a flow rate of $50 \mathrm{~mL} \mathrm{~min}^{-1}$ to room temperature. The prepared coal-derived carbon catalysts are denoted as MC800, MC950, MC1050 and MC1100, respectively.

To prepare $\mathrm{Co} / \mathrm{CoO}_{\mathrm{x}}$ decorated $\mathrm{MC}$ catalyst, cobalt acetate was added to a $20 \mathrm{~mL} \mathrm{MC}$ aqueous suspension $\left(3 \mathrm{mg} \mathrm{mL}^{-1}\right)$ with an initial Co to MC weight ratio of $1,5,10,20,30,40$ and $50 \%$. The suspension was subsequently ultrasonicated for 90 minutes at room temperature with an ultrasonic cell grinder (Scientz, China) and transferred to a microwave reactor (Yuhua, China) to form $\mathrm{Co} / \mathrm{CoO}_{\mathrm{x}}-\mathrm{MC}$ composites under a constant power of microwave $(720 \mathrm{~W})$ for 3 cycles with $30 \mathrm{~s}$ "on" and $60 \mathrm{~s}$ "off". During this process, the solution was continuously stirred. Then the solution was washed with distilled water to remove unreacted salts until the filtrate solution was clear. The sample was freeze dried at $-55^{\circ} \mathrm{C}$ for $12 \mathrm{~h}$ in a freeze dryer (Boyikang, China) to finally obtain the resultant catalyst powder. The prepared catalysts are denoted as $\mathrm{Co} / \mathrm{CoO}_{\mathrm{x}} 1-\mathrm{MC} 1050, \mathrm{Co} / \mathrm{CoO}_{\mathrm{x}} 5$ $\mathrm{MC} 1050, \mathrm{Co} / \mathrm{CoO}_{\mathrm{x}} 10-\mathrm{MC} 1050, \mathrm{Co} / \mathrm{CoO}_{\mathrm{x}} 20-\mathrm{MC} 1050, \mathrm{Co} / \mathrm{CoO} \mathrm{x}_{\mathrm{x}} 30-$ $\mathrm{MC} 1050, \mathrm{Co} / \mathrm{CoO}_{\mathrm{x}} 40-\mathrm{MC} 1050$, and $\mathrm{Co} / \mathrm{CoO}_{\mathrm{x}} 50-\mathrm{MC} 1050$, respectively. The reference $\mathrm{Co} / \mathrm{CoO}_{\mathrm{x}}$ sample was prepared in a similar way by adding cobalt acetate to deionized distilled water, followed by the same above-mentioned treatment process. During microwave treatment, the metal cobalt acetate and solvent water absorb microwave radiation leading to rapid internal heating and decomposition of the metal salt to form the corresponding oxide. The agitation forces caused by the microwave heating process induce homogenous deposition of the metal oxide on the carbon matrix.

Electrochemical measurements.-The pretreatment procedure of the rotating disk electrode (RDE) $(\varnothing=5 \mathrm{~mm}$, glassy carbon) used as the catalyst support for the electrochemical measurements followed our previous work. ${ }^{30,31}$ Briefly it was first polished on a polishing cloth (LECO, USA) using $\mathrm{Al}_{2} \mathrm{O}_{3}$-pastes of different grain sizes (1, and $0.3 \mu \mathrm{m}$ ), followed by rinsing with water. $5 \mathrm{mg}$ of the catalyst powder was dispersed in a mixture of water, ethanol and Nafion $(5 \%)$ with a volume ratio of $490 \mu \mathrm{l}: 490 \mu \mathrm{l}: 20 \mu \mathrm{l}$ with the aid of ultrasonication for $30 \mathrm{~min}$ to prepare catalyst inks. $8.3 \mu \mathrm{l}$ catalyst suspension corresponding to a loading of $0.210 \mathrm{mg} \mathrm{cm}^{-2}$ was carefully dropcoated on the RDE. The electrode was left to dry at room temperature in air for at least $30 \mathrm{~min}$ before being investigated for the oxygen evolution reaction (OER). The electrochemical performances of the composites were investigated by a CHI760E potentiostat/galvanostat (CH Instruments, China) in combination with a speed control unit (PINE Research Instrumentation, USA) in $\mathrm{NaOH}$ solution saturated with $\mathrm{O}_{2}$. A Pt-stick and a $\mathrm{Ag} / \mathrm{AgCl} / 3 \mathrm{M} \mathrm{KCl}$ electrode were used as counter electrode and reference electrode, respectively. The potential was scanned between 0 to $1.0 \mathrm{~V}$ at a scan rate of $5 \mathrm{mV} \mathrm{s}^{-1}$, with the electrolyte saturated with $\mathrm{O}_{2}$. The rotation speed of the RDE was maintained at $1600 \mathrm{rpm}$. The long-term stability test was first performed at a constant current density of $10 \mathrm{~mA} \mathrm{~cm}^{-2}$ for $66 \mathrm{~h}$ in $\mathrm{O}_{2}$-saturated 1.0 $\mathrm{M} \mathrm{NaOH}$ solution using a graphite electrode $(\varnothing=6 \mathrm{~mm})$ with the same catalyst loading $\left(0.210 \mathrm{mg} \mathrm{cm}^{-2}\right)$. Another durability test was also carried out by running 1000 cyclic voltammograms in the range of 0 to $0.6 \mathrm{~V}$ vs. $\mathrm{Ag} / \mathrm{AgCl} / 3 \mathrm{M} \mathrm{KCl}$ reference electrode at a scan rate of $100 \mathrm{mV} \mathrm{s}^{-1}$ in $\mathrm{O}_{2}$-saturated $1.0 \mathrm{M} \mathrm{NaOH}$. For both cases, the linear sweep voltammograms before and after the test has been recorded for comparison. The potentials in the study are reported with respect to the reversible hydrogen electrode (RHE), according to the conversion $\mathrm{E}=\mathrm{E}_{0}+\mathrm{E}_{\mathrm{Ag} / \mathrm{AgCl}}+0.059^{*} \mathrm{pH}-\mathrm{iR}_{\mathrm{s}}$, where $\mathrm{E}_{0}$ is the measured potential vs. $\mathrm{Ag} / \mathrm{AgCl} / 3 \mathrm{M} \mathrm{KCl}, \mathrm{E}_{\mathrm{Ag} / \mathrm{AgCl}}$ is $0.207 \mathrm{~V}$ for the standard potential of the $\mathrm{Ag} / \mathrm{AgCl} / 3 \mathrm{M} \mathrm{KCl}$ reference electrode with respect to the standard hydrogen electrode at zero $\mathrm{pH}, \mathrm{R}_{\mathrm{s}}$ is the electrolyte resistance read out directly from the $\mathrm{CHI}$ software at the open circuit potential and $\mathrm{i}$ is the electrocatalytic OER current.

Characterization of samples.-Transmission electron microscopy (TEM) (HITACHI H-600) and scanning electron microscopy (SEM) (HITACHI SU8010) were applied to characterize the morphologies of $\mathrm{MC} 1050$ and $\mathrm{Co} / \mathrm{CoO}_{\mathrm{x}}-\mathrm{MC} 1050$. A D8 (Bruker) X-ray diffractometer with $\mathrm{Cu} \mathrm{K}_{\alpha}$ radiation $(\lambda=1.5418 \AA$ ) and a Bruker spectrometer with a $532 \mathrm{~nm}$ laser source were used for recording Xray diffraction (XRD) patterns and Raman spectra, respectively. An ESCALab250Xi electron spectrometer with a $300 \mathrm{~W}$ Al $\mathrm{K}_{\alpha}$ radiation source was applied for X-ray photoelectron spectroscopy (XPS) measurements.

\section{Results and Discussion}

The electrochemical performance of the $\mathrm{MC}$ and $\mathrm{Co} / \mathrm{CoO}_{\mathrm{x}}-\mathrm{MC}$ catalysts toward the OER was characterized by linear sweep voltammetry (LSV) in $\mathrm{O}_{2}$-saturated $0.5 \mathrm{M} \mathrm{NaOH}$ solution $(\mathrm{pH}$ 13.7) at a scan rate of $5 \mathrm{mV} \mathrm{s}^{-1}$. During the measurements, the electrode was continuously rotated at $1600 \mathrm{rpm}$ to prevent gas bubble accumulation on the electrode surface. Figure 1A presents the polarization curves of MC1050 and after its modification with different loadings of $\mathrm{Co} / \mathrm{CoO}_{\mathrm{x}}$, as well as the $\mathrm{Co} / \mathrm{CoO}_{\mathrm{x}}$ sample as reference. $\mathrm{MC} 1050$ displayed insignificantly low anodic currents compared to its counterparts modified with $\mathrm{Co} / \mathrm{CoO}_{\mathrm{x}}$ thus indicating poor activity in electro catalyzing the OER. In contrast, very promising OER activity was observed in the case of the $\mathrm{Co} / \mathrm{CoO}_{\mathrm{x}}-\mathrm{MC} 1050$ composites clearly highlighted by two important features, that is, a significant negative shift of the OER onset potential and a positive increase of the OER current density. The onset potential for oxygen evolution, defined as the potential corresponding to a current density of $1 \mathrm{~mA}$ $\mathrm{cm}^{-2}$, on $\mathrm{Co} / \mathrm{CoO}_{\mathrm{x}} 40-\mathrm{MC} 1050$ was $1.610 \mathrm{~V}$, which was the smallest among the investigated samples. $\mathrm{Co} / \mathrm{CoO}_{\mathrm{x}} 40-\mathrm{MC} 1050$ also required the least potential $(1.664 \mathrm{~V})$, compare to the other samples, $\mathrm{Co} / \mathrm{CoO}_{\mathrm{x}} 50-\mathrm{MC} 1050(1.711 \mathrm{~V}), \mathrm{Co} / \mathrm{CoO}_{\mathrm{x}} 30-\mathrm{MC} 1050(1.709 \mathrm{~V})$, $\mathrm{Co} / \mathrm{CoO}_{\mathrm{x}} 20-\mathrm{MC} 1050$ (1.738 V), $\mathrm{Co} / \mathrm{CoO}_{\mathrm{x}} 10-\mathrm{MC} 1050$ (1.789 V), $\mathrm{Co} / \mathrm{CoO}_{\mathrm{x}} 5-\mathrm{MC} 1050(1.773 \mathrm{~V}), \mathrm{Co} / \mathrm{CoO}_{\mathrm{x}} 1-\mathrm{MC} 1050(1.809 \mathrm{~V})$, as well as pure $\mathrm{Co} / \mathrm{CoO}_{\mathrm{x}}(1.731 \mathrm{~V})$ to reach $10 \mathrm{~mA} \mathrm{~cm}{ }^{-2}$. A current density of $10 \mathrm{~mA} \mathrm{~cm}{ }^{-2}$ has been proposed as the figure of merit for estimating the efficiency of a given OER catalyst for viable solar driven fuel synthesis. ${ }^{32}$ The inclusion of cobalt thus evidently promoted the OER activity. However, the decrease of the electrochemical performance with increase of the amount of the cobalt precursor above $50 \%$ might be due to agglomeration of $\mathrm{Co} / \mathrm{CoO}_{\mathrm{x}}$ particles, which decrease the active surface area exposed to the solution. In addition, a high coverage with $\mathrm{Co} / \mathrm{CoO}_{\mathrm{x}}$ in relation to carbon seems to mask the potential contribution of carbon as a conductive matrix thereby diminishing the charge transfer rate. The influence of the thermal treatment temperature of $\mathrm{MC}$ in $\mathrm{NH}_{3} / \mathrm{Ar}$ on the electrocatalytic performance of the microwave-synthesized $\mathrm{Co} / \mathrm{CoO}_{\mathrm{x}}$ toward OER was subsequently studied as shown Figure $1 \mathrm{~B} . \mathrm{Co} / \mathrm{CoO}_{\mathrm{x}} 40-\mathrm{MC} 1050$ displayed the best OER performance with respect to the onset potential for the OER at $1 \mathrm{~mA} \mathrm{~cm}^{-2}\left(\mathrm{E}_{\text {onset }}=1.610 \mathrm{~V}\right)$, and the potential necessary to attain a current density of $10 \mathrm{~mA} \mathrm{~cm}^{-2}\left(\mathrm{E}_{10}=1.664 \mathrm{~V}\right)$, which were both much better than $\mathrm{Co} / \mathrm{CoO}_{\mathrm{x}} 40-\mathrm{MC} 950\left(\mathrm{E}_{\text {onset }}=1.627 \mathrm{~V}\right.$ and $\left.\mathrm{E}_{10}=1.685 \mathrm{~V}\right)$ and $\mathrm{Co} / \mathrm{CoO}_{\mathrm{x}} 40-\mathrm{MC} 800\left(\mathrm{E}_{\text {onset }}=1.644 \mathrm{~V}\right.$ and $\left.\mathrm{E}_{10}=1.718 \mathrm{~V}\right)$, except $\mathrm{Co} / \mathrm{CoO}_{\mathrm{x}} 40-\mathrm{MC} 1100$ that attained nearly similar values $\left(\mathrm{E}_{\text {onset }}=\right.$ $1.614 \mathrm{~V}$ and $\left.\mathrm{E}_{10}=1.667 \mathrm{~V}\right)$. High-temperature treatment would favor the incorporation of nitrogen into the lattice positions of carbon forming graphitic nitrogen thus leading to the increase of structure disorder with more surface and edge defects, which would favor the subsequent introduction of $\mathrm{Co} / \mathrm{CoO}_{\mathrm{x}} \cdot{ }^{31,33}$ Further to this, high temperature 
A

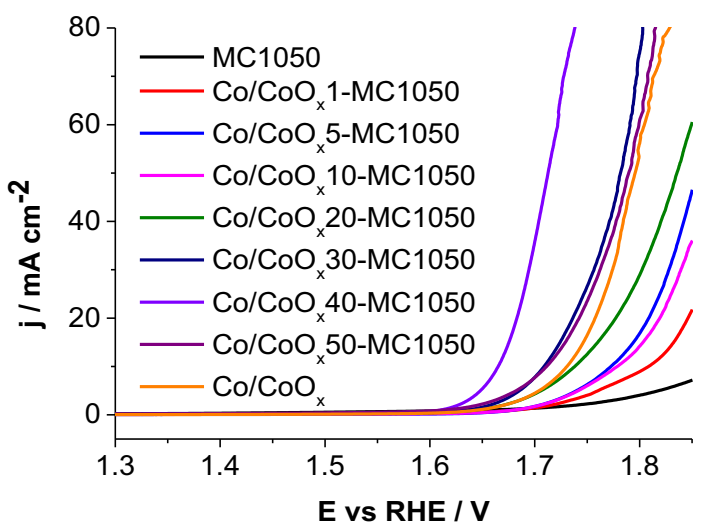

C

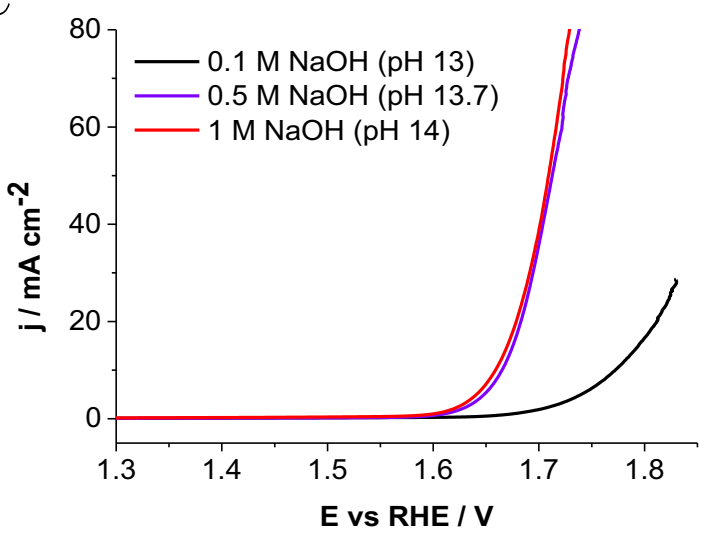

E

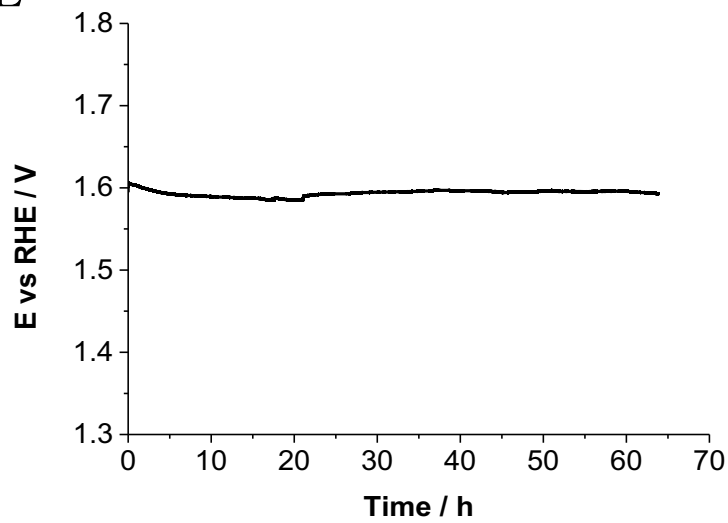

$\mathrm{B}$

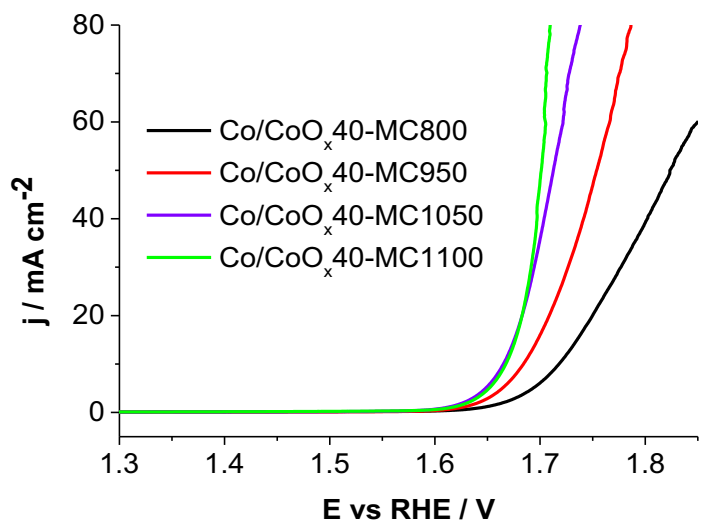

D

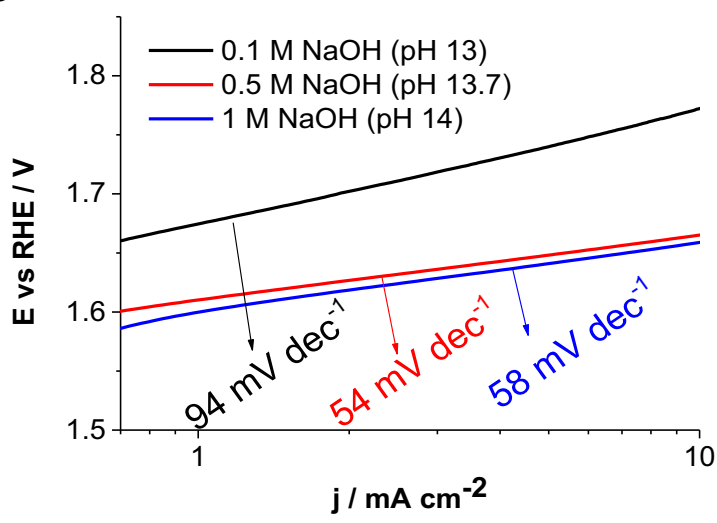

F

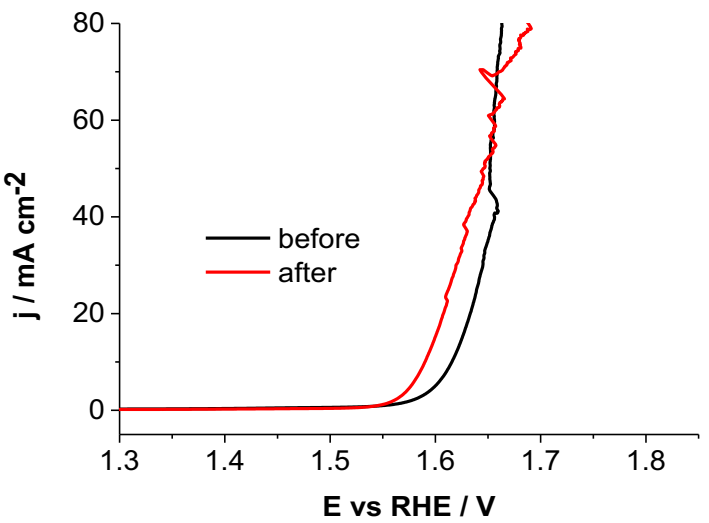

Figure 1. Linear sweep voltammograms (iR drop corrected) showing the electrocatalytic activity toward OER of (A) pure Co/CoO $\mathrm{x}_{\mathrm{x}}$ and $\mathrm{MC} 1050$, and $\mathrm{MC} 1050 \mathrm{mod}-$ ified with different loadings of $\mathrm{Co} / \mathrm{CoO}_{\mathrm{x}}$; (B) $\mathrm{MC}$ modified with $\mathrm{Co} / \mathrm{CoO}_{\mathrm{x}}$ and thermally treated at different temperatures, namely: $800^{\circ} \mathrm{C}, 950^{\circ} \mathrm{C}, 1050^{\circ} \mathrm{C}$ and $1100^{\circ} \mathrm{C}$; (C) OER activity of $\mathrm{Co} / \mathrm{CoO}_{\mathrm{x}} 40-\mathrm{MC} 1050$ in $\mathrm{O}_{2}$-saturated $\mathrm{NaOH}$ at different concentrations that is: $0.1,0.5$ and $1 \mathrm{M} \mathrm{NaOH}$. The electrode was maintained at a rotation speed of $1600 \mathrm{rpm}$ and scan rate of $5 \mathrm{mV} \mathrm{s}^{-1}$ during the measurements; (D) Tafel slopes derived from (C); (E) long-term chronoamperometric stability test of $\mathrm{Co} / \mathrm{CoO}_{\mathrm{x}} 40-\mathrm{MC} 1050$ supported on a graphite electrode at a constant current density of $10 \mathrm{~mA} \mathrm{~cm}^{-2}$ in $\mathrm{O}_{2}$-saturated $1 \mathrm{M} \mathrm{NaOH}$; (F) Linear sweep voltammograms before and after the experiment in $(\mathrm{E})$.

annealing of carbon, especially in the presence of transition metal species is known to increase the graphitic degree of the carbon as well as its conductivity. The electrochemical impedance spectra (EIS) of MC samples thermally treated at different temperatures were investigated at $1.65 \mathrm{~V}$ vs. RHE over the frequency range from $100 \mathrm{kHz}$ to $0.01 \mathrm{~Hz}$ in $1.0 \mathrm{M} \mathrm{NaOH}$ or $5 \mathrm{mM} \mathrm{K}$ [ $\left[\mathrm{Fe}(\mathrm{CN})_{6}\right]$ in $1.0 \mathrm{M} \mathrm{NaOH}$ solution. When recording the impedance in $1.0 \mathrm{M}$ $\mathrm{NaOH}$, it was not straightforward to determine the charge resistance from the resulting Nyquist plots due to the complexity and heterogeneous nature of the system. EIS was thus also measured in a solution of $5 \mathrm{mM} \mathrm{K}_{3}\left[\mathrm{Fe}(\mathrm{CN})_{6}\right]$ in $1.0 \mathrm{M} \mathrm{NaOH}$. In this case, during ac perturbation at the open circuit potential of the established $\mathrm{Fe}^{3+/} \mathrm{Fe}^{2+}$ redox couple, the measured charge transfer resistance from the Nyquist plots corresponds to resistance to electron transfer across the catalyst films owing to the high reversibility of the $\mathrm{Fe}^{3+/} \mathrm{Fe}^{2+}$ redox couple (Figure S3). The electrochemically active surface area of the prepared samples i.e. $\mathrm{Co} / \mathrm{CoO}_{\mathrm{x}}-\mathrm{MC} 800, \mathrm{Co} / \mathrm{CoO}{ }^{-}$ $\mathrm{MC} 950, \mathrm{Co} / \mathrm{CoO}_{\mathrm{x}}-\mathrm{MC} 1050$, and $\mathrm{Co} / \mathrm{CoO}_{\mathrm{x}}-\mathrm{MC} 1100$, loaded on the glassy carbon electrode are calculated to be $14.65,25.25,24.70$, and $27.85 \mathrm{~cm}^{2}$, by running cyclic voltammetry in the range of 1 to $1.15 \mathrm{~V}$ vs. RHE at different at different scan rates $(5,10,20$, 50,100 and $200 \mathrm{mV} \mathrm{s}^{-1}$ ) (Figure S4). The OER performance of 
Table I. A comparison of the performance of cobalt-based materials as OER catalysts based on recent literature.

\begin{tabular}{|c|c|c|c|c|c|c|}
\hline Sample & $\begin{array}{l}\text { Catalyst loading } \\
\left(\mathrm{mg} \mathrm{cm}^{-2}\right)\end{array}$ & Electrolyte & $\begin{array}{c}E_{\mathrm{OER}}(\mathrm{V}) @ \\
10 \mathrm{~mA} \mathrm{~cm}{ }^{-2}\end{array}$ & $\eta_{\mathrm{OER}}(\mathrm{V})$ & $\begin{array}{l}\text { Tafel slope } \\
\left(\mathrm{mV} \mathrm{dec}^{-1}\right)\end{array}$ & Ref. \\
\hline $\begin{array}{c}\mathrm{Co} @ \mathrm{CoO} @ \mathrm{CO}_{3} \mathrm{O}_{4}- \\
\text { N/C }\end{array}$ & 0.25 & $\mathrm{O}_{2}$-sat. $1 \mathrm{M} \mathrm{NaOH}$ & 1.680 & 0.45 & 39 & 34 \\
\hline $\mathrm{Co}(\mathrm{OH})_{2} \mathrm{NPs}$ & 0.1 & $\mathrm{O}_{2}$-sat. $1 \mathrm{M} \mathrm{NaOH}$ & 1.559 & 0.339 & 40 & 35 \\
\hline $\mathrm{Co}_{3} \mathrm{O}_{4}$ & 0.22 & $1 \mathrm{M} \mathrm{KOH}$ & 1.655 & 0.425 & 44 & 36 \\
\hline $\mathrm{Co} / \mathrm{Co}_{3} \mathrm{O}_{4} 40-\mathrm{NG}$ & 0.21 & $\mathrm{O}_{2}$-sat. $1 \mathrm{M} \mathrm{NaOH}$ & 1.667 & 0.437 & 99 & 37 \\
\hline CoP/CDs- $18.97 \%$ & 0.35 & $1 \mathrm{M} \mathrm{KOH}$ & 1.61 & 0.4 & 93 & 38 \\
\hline $\begin{array}{l}\text { De-LCO NPs } \\
\quad\left(\mathrm{LiCoO}_{2}\right)\end{array}$ & 0.1 & $0.1 \mathrm{M} \mathrm{KOH}$ & 1.62 & 0.39 & 57 & 40 \\
\hline $\mathrm{Co}_{3} \mathrm{O}_{4}-\mathrm{C}$ & 1.76 & $1 \mathrm{M} \mathrm{KOH}$ & 1.609 & 0.38 & 78 & 41 \\
\hline $\mathrm{RuO}_{2}$ & 0.21 & $\mathrm{O}_{2}$-sat. $1 \mathrm{M} \mathrm{KOH}$ & 1.64 & 0.41 & - & 42 \\
\hline $\mathrm{IrO}_{2}$ & 0.21 & $\mathrm{O}_{2}$-sat. $1 \mathrm{M} \mathrm{KOH}$ & 1.70 & 0.47 & - & 42 \\
\hline
\end{tabular}

${ }^{a}$ The potential was initially reported vs. $\mathrm{Ag} / \mathrm{AgCl} / 3 \mathrm{M} \mathrm{KCl}$, and it was corrected vs. RHE in this table.

$\mathrm{Co} / \mathrm{CoO}_{\mathrm{x}} 40-\mathrm{MC} 1050$ was further characterized in $\mathrm{O}_{2}$-saturated $0.1 \mathrm{M}$ $\mathrm{NaOH}(\mathrm{pH} 13)$ and $1 \mathrm{M} \mathrm{NaOH}(\mathrm{pH} 14)$, respectively in order to study the influence of the electrolyte $\mathrm{pH}$. Better electrocatalytic performance of the catalyst was achieved with increase of the $\mathrm{NaOH}$ concentration. This is not surprising because the $\mathrm{OH}^{-}$ions are reactants in the OER in alkaline solution, according to the equation: $4 \mathrm{OH}^{-} \rightarrow$ $\mathrm{O}_{2}+2 \mathrm{H}_{2} \mathrm{O}+4 \mathrm{e}^{-}$. Therefore, increase of the $\mathrm{NaOH}$ concentration would accelerate the kinetics of the OER by increasing the exchange current density, which is directly correlated with the $\mathrm{OH}^{-}$concentration. The potential required to obtain a current density of $1 \mathrm{~mA} \mathrm{~cm}^{-2}$ and $10 \mathrm{~mA} \mathrm{~cm} \mathrm{~m}^{-2}$ was 1.600 and $1.659 \mathrm{~V}$, respectively, with corresponding overpotentials $(\eta)$ of 0.370 and $0.429 \mathrm{~V}$, when $\mathrm{Co} / \mathrm{CoO}_{\mathrm{x}} 40$ MC1050 was characterized in $\mathrm{O}_{2}$-saturated $1 \mathrm{M} \mathrm{NaOH}$. This performance is comparable to that reported for the state-of-the-art cobaltbased OER catalysts and commercial $\mathrm{RuO}_{2}$, and surpasses some of advanced carbon materials (e.g. graphene or carbon nanotubes) supported cobalt-based catalysts and commercial $\mathrm{IrO}_{2}$ (Table I). ${ }^{34-42}$ Figure 1D shows the Tafel plots of the $\mathrm{Co} / \mathrm{CoO}_{\mathrm{x}} 40-\mathrm{MC} 1050$ characterized in different $\mathrm{NaOH}$ solutions derived from Figure $1 \mathrm{C}$. The Tafel slopes were 54 and $58 \mathrm{mV} \mathrm{dec}^{-1}$ for the $\mathrm{Co} / \mathrm{CoO}_{\mathrm{x}} 40-\mathrm{MC} 1050$ characterized in $0.5 \mathrm{M}$ and $1 \mathrm{M} \mathrm{NaOH}$, respectively, much lower than in $0.1 \mathrm{M} \mathrm{NaOH}$ $\left(94 \mathrm{mV} \mathrm{dec}^{-1}\right)$. From the general expression for the Tafel slope of an electrode reaction: $b=\frac{2.303 \mathrm{RT}}{\alpha \mathrm{F}}$, where $\mathrm{R}$ is the universal gas constant $\left(8.314 \mathrm{~J} \mathrm{~K}^{-1} \mathrm{~mol}^{-1}\right), \mathrm{T}$ is the temperature $(298 \mathrm{~K}), \alpha$ is the transfer coefficient, and $\mathrm{F}$ is the Faraday constant $\left(96485 \mathrm{C} \mathrm{mol}^{-1}\right)$, a slope of $\sim 118.3 \mathrm{mV} \mathrm{dec}^{-1}$, assuming $\alpha=0.5$, would be expected if the first electron transfer step (i) in the OER mechanism outlined below is rate limiting. $\mathrm{M}+\mathrm{OH}^{-} \rightarrow \mathrm{MOH}+\mathrm{e}^{-}$(i); $\mathrm{M}_{-} \mathrm{OH}_{\mathrm{ads}}(\mathrm{A}) \rightarrow \mathrm{M}-\mathrm{OH}_{\mathrm{ads}}(\mathrm{B})$ (i'), A and B denoting surface sites characterized by different energy levels which is typical of heterogeneous catalysts, as in the present case of $\mathrm{Co} / \mathrm{CoO}_{\mathrm{x}}-\mathrm{MC}$, due to surface diffusion during the OER. ${ }^{43,44}$ $\mathrm{MOH}+\mathrm{OH}^{-} \rightarrow \mathrm{MO}+\mathrm{H}_{2} \mathrm{O}+\mathrm{e}^{-}(\mathrm{ii}) ; \mathrm{MO}+\mathrm{OH}^{-} \rightarrow \mathrm{MOOH}+\mathrm{e}^{-}$ (iii); $\mathrm{MOOH}+\mathrm{OH}^{-} \rightarrow \mathrm{MO}_{2}+\mathrm{H}_{2} \mathrm{O}+\mathrm{e}^{-}$(iv); and $\mathrm{MO}_{2} \rightarrow \mathrm{M}+\mathrm{O}_{2}$ (v). In the case of an anodic reaction, the anodic transfer coefficient $\alpha_{a}$ is defined as: $\alpha_{a}=\mathbf{r} \cdot(\mathbf{1}-\boldsymbol{\beta})+\mathbf{n}^{\prime} / \mathbf{v}$, where $\beta$ is the symmetry factor, $\nu$ is the stoichiometric number, $\mathrm{n}^{\prime}$ is the total number of electrons exchanged in the elementary steps preceding the rate determining step (RDS) in the mechanism, and $r$ is a factor that can have only two values: 0 or 1 , when the RDS is a chemical or electrochemical step, respectively. ${ }^{45-47}$ If the chemical step after the first electron transfer is rate limiting, A Tafel slope of $\sim 59.2 \mathrm{mV} \mathrm{dec}^{-1}$ is obtained. If the second electron transfer step of the OER (step (ii)) is rate limiting, a Tafel slope of $\sim 40 \mathrm{mV} \mathrm{dec}{ }^{-1}$ would be obtained. The existence of a Tafel slope of about $118 \mathrm{mV} \mathrm{dec}{ }^{-1}$ implies kinetically slow adsorption of the $\mathrm{OH}_{\text {ads }}$ intermediate (step (i)), so that a low surface coverage of the electrode with adsorbed reaction intermediates is expected in the entire OER potential region. The observed Tafel slopes of $54 \mathrm{mV} \mathrm{dec}^{-1}$, $58 \mathrm{mV} \mathrm{dec}^{-1}$ and $94 \mathrm{mV} \mathrm{dec}^{-1}$ of the OER on $\mathrm{Co} / \mathrm{CoO}_{\mathrm{x}} 40-\mathrm{MC} 1050$ in $0.5,1.0$, and $0.1 \mathrm{M} \mathrm{NaOH}$, respectively, thus indicate that the OER was considerably kinetically faster in $0.5 \mathrm{M}$ and $1.0 \mathrm{M} \mathrm{NaOH}$ compared to $0.1 \mathrm{M} \mathrm{NaOH}$. At lower $\mathrm{NaOH}$ concentration $(0.1 \mathrm{M} \mathrm{NaOH})$, the formation of adsorbed $\mathrm{OH}^{-}$species in the primary discharge step $\left(\mathrm{M}+\mathrm{OH}^{-} \rightarrow \mathrm{MOH}+\mathrm{e}^{-}\right)$and subsequent surface diffusion seem to be the limiting factors for the overall OER rate. On the other hand, the smaller values of the Tafel slope at higher $\mathrm{NaOH}$ concentrations $(0.5$ or $1 \mathrm{M} \mathrm{NaOH})$ are certainly due to a different rate controlling elementary step, either $\mathrm{M}-\mathrm{OH}_{\mathrm{ads}}(\mathrm{A}) \rightarrow \mathrm{M}-\mathrm{OH}_{\mathrm{ads}}$ (B) or $\mathrm{M}-\mathrm{OH}_{\mathrm{ads}}$ $+\mathrm{OH}_{-} \rightarrow \mathrm{M}-\mathrm{O}_{\mathrm{ads}}+\mathrm{H}_{2} \mathrm{O}+\mathrm{e}^{-} .{ }^{48-50}$ The Tafel plots for different $\mathrm{Co} / \mathrm{CoO}_{\mathrm{x}}-\mathrm{MC} 1050$ samples with different $\mathrm{Co} / \mathrm{CoO}_{\mathrm{x}}$ loadings derived from Figure $1 \mathrm{~A}$ and the samples of $\mathrm{Co} / \mathrm{CoO}_{\mathrm{x}} 40$ loaded on $\mathrm{MC}$ thermally treated at different temperatures, derived from Figure $1 \mathrm{~B}$, are also presented in Figure S1. It is anticipated that an optimal morphology should favor rapid $\mathrm{OH}^{-}$diffusion and adsorption to the catalyst surfaces, such that, the rate-control step is exclusively dependent on the intrinsic catalyst properties. One of the most important concerns on applying carbon-based material as OER catalysts is whether they can remain stable under the strongly oxidative conditions during the OER. Moreover, a stable catalytic performance in high-concentration alkaline solutions is critical for realistic applications. ${ }^{51}$ Therefore, a long-term stability chronopotentiometric test was performed by applying a constant current density of $10 \mathrm{~mA} \mathrm{~cm}^{-2}$ in $1 \mathrm{M} \mathrm{NaOH}$ with $\mathrm{Co} / \mathrm{CoO}_{\mathrm{x}} 40-\mathrm{MC} 1050$ deposited on a graphite electrode as the support. The potential response was stable for the investigated period of at least 66 hours, moreover, a slight decrease of the overpotential was observed (Figure 1E). Additionally, linear sweep voltammograms were also recorded before and after the chronopotentiometric experiment (Figure 1F). The LSVs further demonstrated that the OER activity of the catalyst was well preserved in the concentrated electrolyte. Slight but noticeable improvement of the OER performance was observed after the long-term chronopotentiometric experiment, which might be due to morphological changes of the catalyst film, particularly, removal of unstable amorphous carbon exposed to the electrolyte due to the forces induced by detachment of the oxygen gas bubbles and concomitant increased accessibility of the $\mathrm{Co} / \mathrm{CoO}_{\mathrm{x}}$ based active sites. On the other hand, all metallic elements when used as catalysts for the OER undergo surface oxidation to form surface oxides, or higher oxides. Metallic cobalt for example is oxidized to cobalt oxide, cobalt oxyhydroxide $(\mathrm{CoOOH})$. Depending on the size of the metallic particles, the oxidation might occur gradually. We previously observed continuous activity enhancement of cobalt and nickel boride and phosphide catalysts due to progressive oxidation of metals with potential cycling, and concomitant increase of the OER activity. ${ }^{52,53}$ Therefore, the fact that the OER activity increases marginally after stability testing is certainly due to oxidation of metallic cobalt and cobalt oxide $(\mathrm{CoO})$ to form cobalt oxyhydroxide $(\mathrm{CoOOH})$, which is believed to be the active state for the OER. We also performed the stability test of 

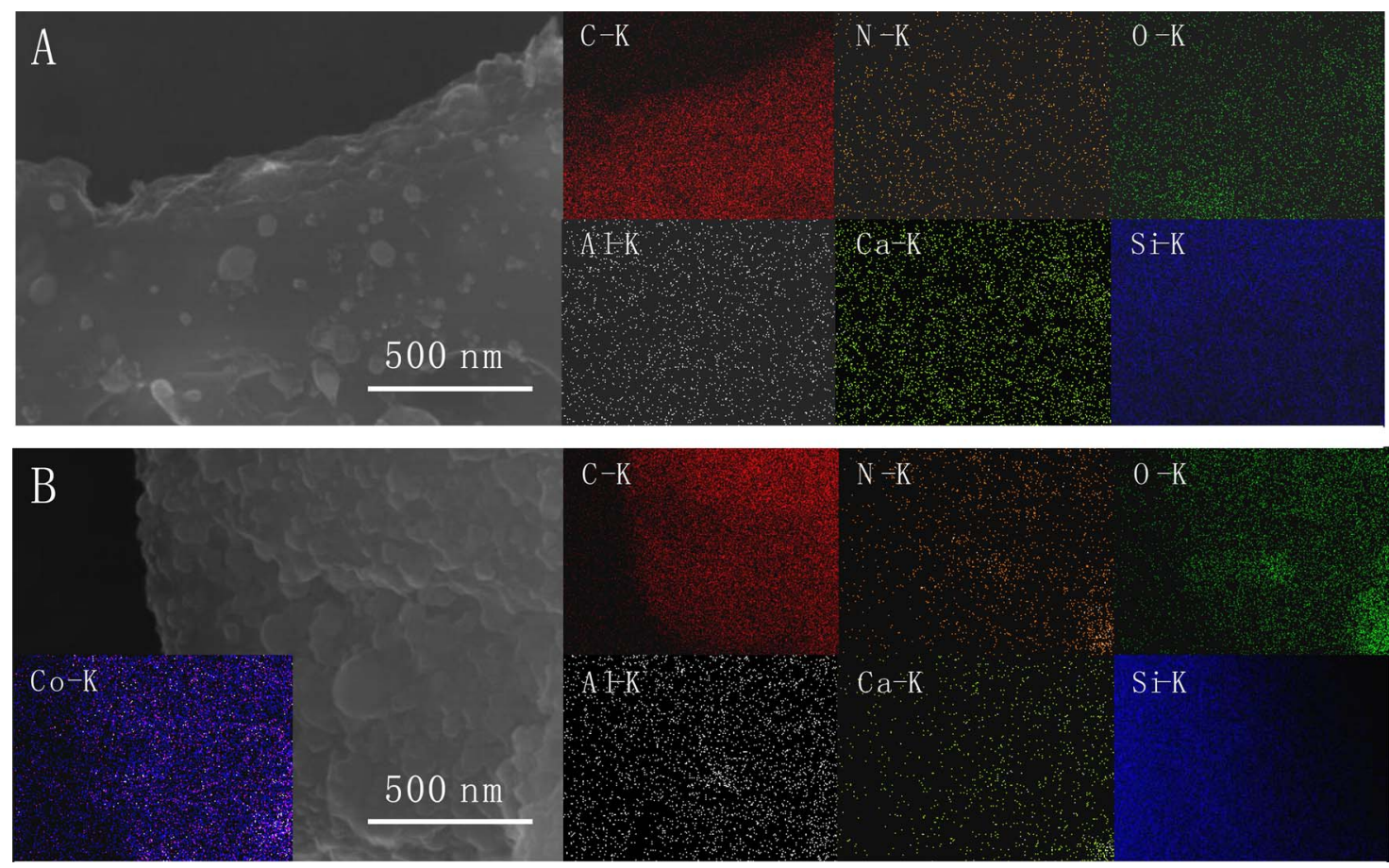

Figure 2. SEM images of (A) $\mathrm{MC} 1050$ and (B) $\mathrm{Co} / \mathrm{CoO}_{\mathrm{x}} 40-\mathrm{MC} 1050$, and the corresponding elemental mapping.

$\mathrm{Co} / \mathrm{CoO}_{\mathrm{x}} 40-\mathrm{MC} 1050$ by running 1000 cyclic voltammograms $(\mathrm{CVs})$ between 0 and $0.6 \mathrm{~V}$ vs. $\mathrm{Ag} / \mathrm{AgCl} / 3 \mathrm{M} \mathrm{KCl}$ at a scan rate of $100 \mathrm{mV} \mathrm{s}^{-1}$ in $1 \mathrm{M} \mathrm{NaOH}$ saturated with oxygen (Figure S2A). Only a marginal change in the CVs was observed. The LSVs recorded before and after $\mathrm{CV}$ measurement also confirmed a negligible decay during the stability test. The potential difference at the current density of $10 \mathrm{~mA}$ $\mathrm{cm}^{-2}$ was only $10 \mathrm{mV}$ (Figure S2B). Because a moderate potential sweep was applied, the strong surface oxidation process would not take place in this case.

To gain further insight into the properties of the prepared catalysts, SEM and EDX elemental mapping were used to study the morphology and chemical composition of MC1050 and the optimized catalyst, $\mathrm{Co} / \mathrm{CoO}_{\mathrm{x}} 40-\mathrm{MC} 1050$ (Figure 2). It is believed that the surface defects in MC1050, including oxygen-functional groups were active sites for the initial nucleation of Co owing to the strong electrostatic interaction between oxygen-functional groups on the surfaces and the Co cations, followed by further growth into 3-dimensional nanoparticles. ${ }^{37}$ As shown in Figure $2 \mathrm{~B}, \mathrm{Co} / \mathrm{CoO}_{\mathrm{x}}$ particles were homogeneously distributed on MC1050. The presence of a higher amount of the cobalt precursor inevitably led to the agglomeration of formed $\mathrm{Co} / \mathrm{CoO}_{\mathrm{x}}$ nanoparticles under high-energy microwave treatment. The corresponding elemental maps of the distribution of $\mathrm{C}, \mathrm{N}, \mathrm{O}$ and $\mathrm{Co}$ are also displayed, clearly confirming the homogeneous distribution of the different elements. Moreover, $\mathrm{Al}, \mathrm{Ca}$, and $\mathrm{Si}$ were also detected, which obviously arise from the ash in the coal.

$\mathrm{Co} / \mathrm{CoO}_{\mathrm{x}} 40-\mathrm{MC} 1050$ was additionally characterized by highresolution TEM in order to probe the nanostructure of the prepared sample in-depth (Figure 3). Figure 3A confirms that a large proportion of the nanoparticles were embedded in the carbon framework. Both metallic $\mathrm{Co}$ and its oxide, $\mathrm{Co}_{3} \mathrm{O}_{4}$, were found to be present, as indicated by the observed lattice fridges with interspacing of 0.205 and $0.244 \mathrm{~nm}$, corresponding to (111) and (311) crystal planes, respectively (Figure 3B). ${ }^{54,55}$ Meanwhile, $\mathrm{Ca}_{2} \mathrm{Al}_{2} \mathrm{SiO}_{7}$ and $\mathrm{SiO}_{2}$ also coexisted in the sample, confirmed by the presence of the crystal lattice spacings of 0.200 and $0.429 \mathrm{~nm}$, assigned to the (212) and (100) crystal planes, respectively. This is consistent with the findings in our previous study where similar species were observed and obviously arise from the impurities in the original coal. ${ }^{31}$ Moreover, the TEM images reveal that the catalyst particles adopt a core-shell like structure with the $\mathrm{Co} / \mathrm{CoO}_{\mathrm{x}}$ nanocrystallites being firmly embedded inside the MC matrix and surrounded with a few layers of graphene $(\mathrm{d}=0.334 \mathrm{~nm})$ (Figure 3C).

The catalyst was further characterized by Raman spectroscopy to obtain insight into the graphitization degree of the carbon materials. Figure 4 shows the Raman spectra of MC1050, and MC1050 modified with the $\mathrm{Co} / \mathrm{CoO}_{\mathrm{x}}$ nanoparticles. The Raman spectra of both MC1050
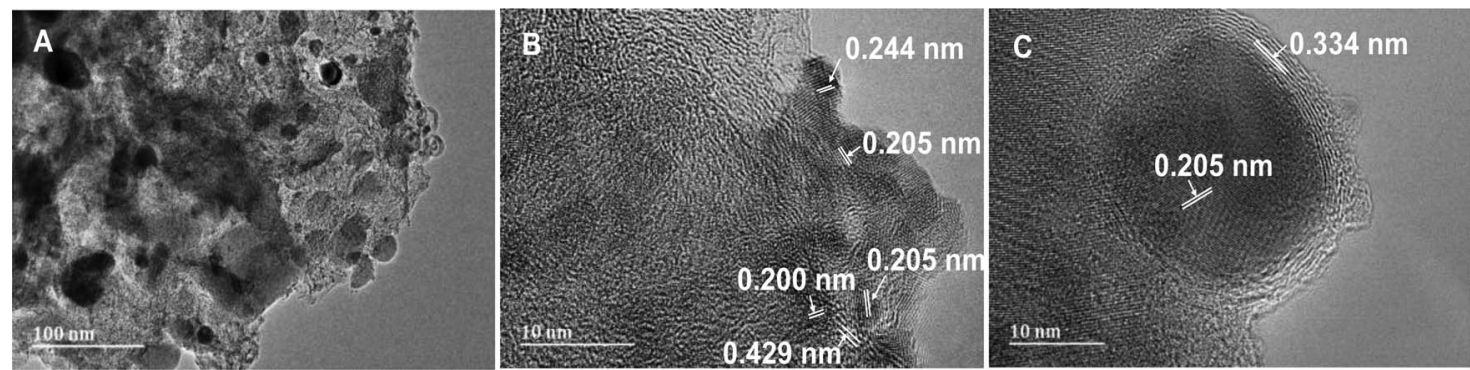

Figure 3. (A) TEM image of $\mathrm{Co} / \mathrm{CoO}_{\mathrm{x}} 40-\mathrm{MC} 1050$, and high-resolution TEM images of (B) metallic $\mathrm{Co}_{0}, \mathrm{Co}_{3} \mathrm{O}_{4}, \mathrm{Ca}_{2} \mathrm{Al}_{2} \mathrm{SiO}_{7}$ and $\mathrm{SiO}_{2}$ nanoparticles; and (C) metallic Co surrounded with graphene layers. 


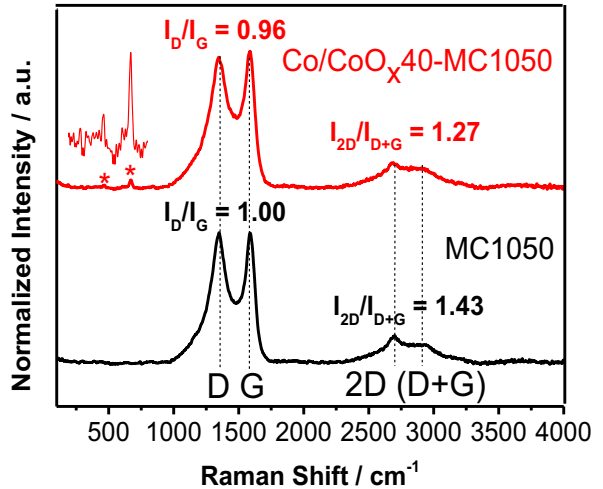

Figure 4. Raman spectra of $\mathrm{MC} 1050$ and $\mathrm{Co} / \mathrm{CoO}_{\mathrm{x}} 40-\mathrm{MC} 1050$ (The spectra were normalized with respect to the corresponding D-bands).

and $\mathrm{Co} / \mathrm{CoO}_{\mathrm{x}} 40-\mathrm{MC} 1050$ exhibit two characteristic main peaks, a Dband at ca. $1350 \mathrm{~cm}^{-1}$ and a G-band at ca. $1588 \mathrm{~cm}^{-1}$, originating from vibration of $\mathrm{sp}^{3}$ carbon atoms due to structural defects and the $\mathrm{E}_{2 \mathrm{~g}}$ vibration mode of $\mathrm{sp}^{2}$ carbon domains, respectively. ${ }^{56,57}$ The intensity ratio of the $\mathrm{D}$ - and $\mathrm{G}$-band $\left(\mathrm{I}_{\mathrm{D}} / \mathrm{I}_{\mathrm{G}}\right)$, were calculated to be 1.00 and 0.96 for $\mathrm{MC} 1050$ and $\mathrm{Co} / \mathrm{CoO}_{\mathrm{x}} 40-\mathrm{MC} 1050$, respectively. The $\mathrm{I}_{\mathrm{D}} / \mathrm{I}_{\mathrm{G}}$ ratio was similar with and without the introduction of $\mathrm{Co} / \mathrm{CoO}_{\mathrm{x}}$ indicating that the synthesis of $\mathrm{Co} / \mathrm{CoO}_{\mathrm{x}}-\mathrm{MC} 1050$ composites did not introduce significant surface defects to MC1050. ${ }^{37}$ The existence of a 2D-band at $2686 \mathrm{~cm}^{-1}$ and a (D+G)-band at $2921 \mathrm{~cm}^{-1}$ provides additional proof for distortion of the aromatic graphitic domains. ${ }^{58,59}$ The $\mathrm{I}_{2 \mathrm{D}} / \mathrm{I}_{\mathrm{D}+\mathrm{G}}$ intensity ratio decreased after the introduction of cobalt, which is ascribed to the coverage of the MC- 1050 surfaces by $\mathrm{Co} / \mathrm{CoO}_{\mathrm{x}}$ nanoparticles and increase of the graphitic degree of the carbon. This also gives a cue that the $\mathrm{Co} / \mathrm{CoO}_{\mathrm{x}}$ nanoparticles prefer to anchor on the surface defects. The peaks at 464 and $663 \mathrm{~cm}^{-1}$ confirm the presence of $\mathrm{Co}_{3} \mathrm{O}_{4} \cdot{ }^{37}$

The XRD spectrum of $\mathrm{Co} / \mathrm{CoO}_{\mathrm{x}} 40-\mathrm{MC} 1050$ was compared with that of MC1050, as shown in Figure 5. Two peaks at $2 \theta=26.6^{\circ}$ and at $44.7^{\circ}$ attributed to (002) and (100) planes of graphitic carbon predominated the diffraction patterns of both $\mathrm{MC} 1050$ and $\mathrm{Co} / \mathrm{CoO} \mathrm{x}_{\mathrm{x}} 40$ MC1050. In addition, both samples contained rather weakly resolved diffraction peaks, similar to our previous observations for related materials. ${ }^{30}$ Particularly, no clear diffraction peaks ascribable to either metallic Co or its oxides were observed in the XRD diffraction patterns, which is partly due a low concentration of $\mathrm{Co}$ and $\mathrm{CoO}_{x}$ species in relation to carbon in these catalysts, and also because the

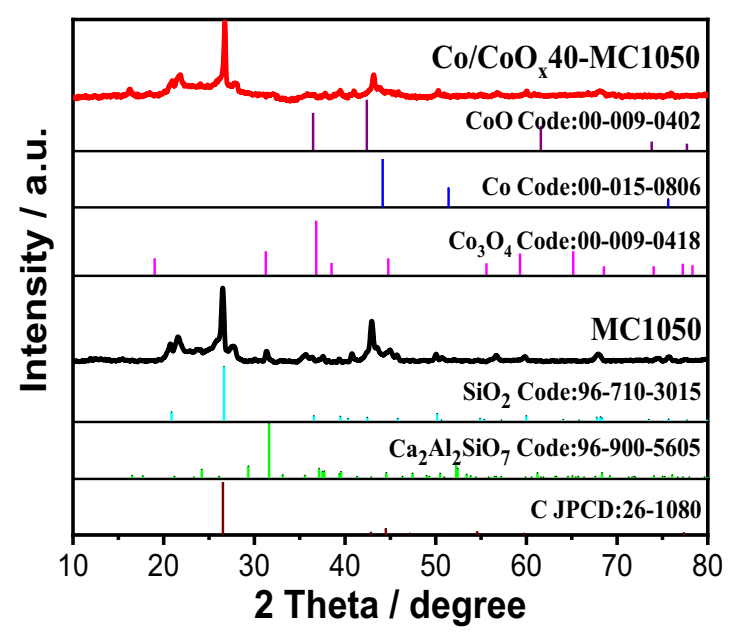

Figure 5. XRD spectra of $\mathrm{MC} 1050$ and $\mathrm{Co} / \mathrm{CoO}_{\mathrm{x}} 40-\mathrm{MC} 1050$. particles are mainly embedded inside graphene layers as revealed by the high-resolution TEM images.

XPS was used to study the chemical state and interaction(s) of the various components (Figure 6). $\mathrm{Co} / \mathrm{CoO}_{\mathrm{x}} 40-\mathrm{MC} 1050$ has clear Co $2 p_{3 / 2}$ and Co $2 p_{1 / 2}$ doublet signals at $782.5 \mathrm{eV}$ and $798.4 \mathrm{eV}$, respectively, with a spin-orbit splitting of $15.9 \mathrm{eV}$ indicating that $\mathrm{Co}^{2+}$ rather than $\mathrm{Co}^{3+}$ species were the dominant oxide form of cobalt (Figure 6A).$^{60}$ The corresponding shoulder peaks at a slightly high binding energy of both peaks are due to a shake-up process, which is generally observed for $\mathrm{Co}^{2+}$ species in the high spin state. ${ }^{61}$ The XPS results therefore further confirm that $\mathrm{CoO}$ was the dominant surface species. In consideration of the TEM results, and the fact that XPS is a surface sensitive technique, the detected $\mathrm{CoO}$ oxide is believed to be a native oxide on the surface of metallic cobalt formed due to atmospheric exposure. The deconvoluted spectrum of the Co $2 \mathrm{p}$ region is dominated by the $\mathrm{Co}^{2+}$ due to $\mathrm{CoO}^{61,62}$ The thermal treatment of cobalt and carbon precursors at high temperature in an ammonia atmosphere in principle leads to the formation of nitrogen functional groups as well as cobalt coordinated to nitrogen within the carbon matrix. The Co-N coordination is weak and the Co-N group has only been observed in very few studies by XPS, where it manifests as a weak shoulder at about $778.8 \mathrm{eV}$, and by X-ray absorption fine structure studies. ${ }^{42}$ In the present XPS studies, the Co-N group was not discernible, nonetheless, its presence cannot be excluded. It should however be noted that the binding energies for both Co $2 \mathrm{p}_{3 / 2}$ and $\mathrm{Co} 2 \mathrm{p}_{1 / 2}$ peaks are slightly higher than those reported for the standard spectra of pure $\mathrm{CoO}$ or $\mathrm{Co}_{3} \mathrm{O}_{4}{ }^{62} \mathrm{~A}$ similar chemical shift of binding energy of Co $2 p_{3 / 2}$ was also observed upon the pyrolysis of cobalt and tetramethoxy-phenyl porphyrin (CoTMPP) at $600^{\circ} \mathrm{C}$ in a nitrogen atmosphere. ${ }^{63}$ The co-existence and interaction of the Co, N, $\mathrm{O}$ and $\mathrm{C}$ active moieties with the other elements and complex oxide species arising from the impurity elements such as $\mathrm{Al}, \mathrm{Mg}, \mathrm{Ca}, \mathrm{Fe}$, $\mathrm{Mn}, \mathrm{Si}$ originally present in the pristine coal, is not to be neglected. ${ }^{31}$ Although not definitively clear at this moment, interaction of the impurity species with the active moieties may lead to modification of the surface electronic structure of the active moieties and ultimately the OER activity of the composite catalyst. In line with this, the slight positive shift in the binding energy of the Co $2 p_{3 / 2}$ and Co $2 p_{1 / 2}$ peaks compared to that of pure cobalt oxide species is most likely due to the interaction of cobalt with the heteroatom elements in the coal. The $\mathrm{O}$ $1 \mathrm{~s}$ peak can be deconvoluted into three peaks (Figure 6B). The two peaks at 531.9 and $533.3 \mathrm{eV}$ are due to the presence of $\mathrm{C}=\mathrm{O}$ and $\mathrm{C}-\mathrm{O}$ functional groups, respectively. The peak centered at $530 \mathrm{eV}$ would relate to anionic oxygen associated with oxide species. The introduction of oxygen functional groups on the surface of carbon materials during nitric acid treatment is commonly observed. ${ }^{64}$ However, in this case, the introduction of cobalt led to a decrease of the total oxygen content, as manifested by the drastic decrease of the intensity of the peak at $531.9 \mathrm{eV}$. This suggests that the $\mathrm{C}=\mathrm{O}$ related groups underwent decomposition during the microwave process. ${ }^{65}$ Moreover, the $\mathrm{C}=\mathrm{O}$ sites could act as potential anchoring sites for the nucleation and growth of cobalt during microwave treatment. Increase in the intensity of the peak at $530 \mathrm{eV}$ upon the introduction of cobalt was not evident. This implies that the amount of oxygen introduced by the formation of cobalt oxide was negligible. On the other hand, XPS is a surface-sensitive technique, a drastic decrease of the amount of the detected oxygen species might be due to the MC1050 covered by $\mathrm{Co} / \mathrm{CoO}_{\mathrm{x}}$ nanoparticles. The $\mathrm{N} 1 \mathrm{~s}$ peak was deconvoluted into three peaks corresponding to pyridinic $(398.4 \mathrm{eV})$, pyrrolic $(400.1 \mathrm{eV})$ and graphitic $(401.3 \mathrm{eV})$ nitrogen (Figure 6C). The influence of surface functionalization by $\mathrm{HNO}_{3}$ vapor and the subsequent thermal treatment in ammonia was previously investigated, ${ }^{30}$ where a decrease of the relative $\mathrm{O} / \mathrm{C}$ ratio was observed accompanied by an increase of the relative $\mathrm{N} / \mathrm{C}$ ratio. Oxygen functional groups created during $\mathrm{HNO}_{3}$ vapor treatment are known to favor the functionalization of carbon with nitrogen atoms during ammonia treatment. The relative concentration of the various nitrogen species varied upon the additional introduction of cobalt as indicated by the specific intensities of the respective species in the deconvoluted $\mathrm{N} 1 \mathrm{~s}$ spectra. The relative ratio of pyridinic 
A

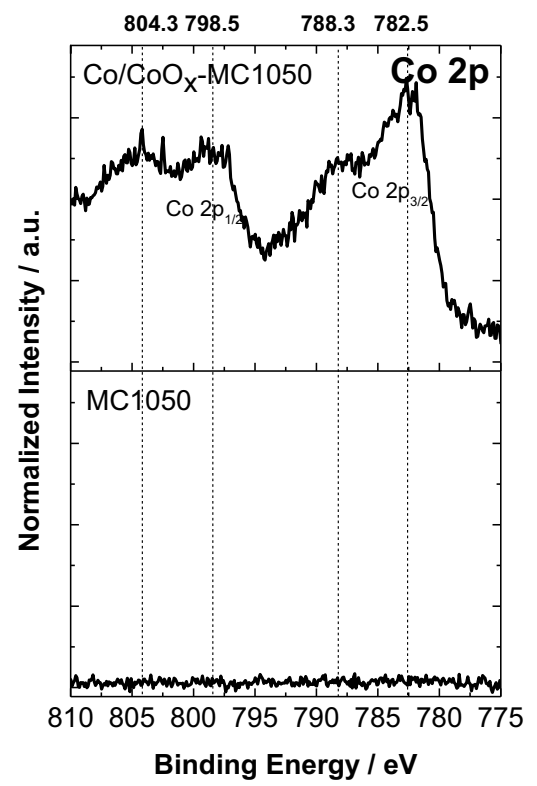

B

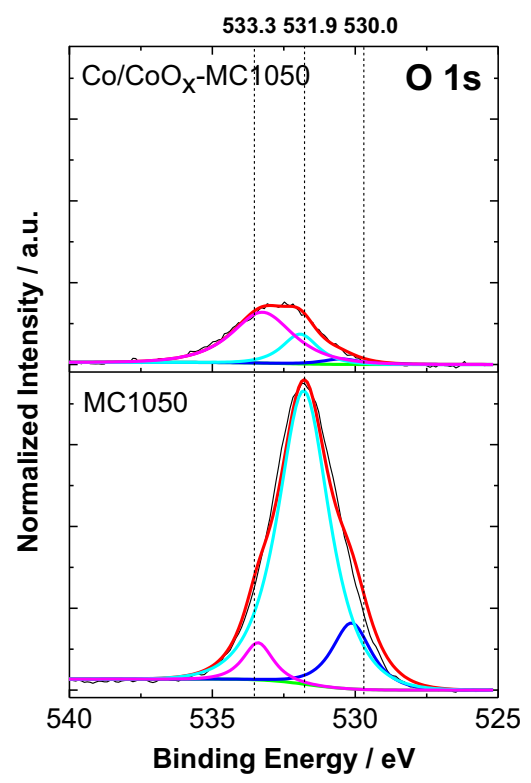

C

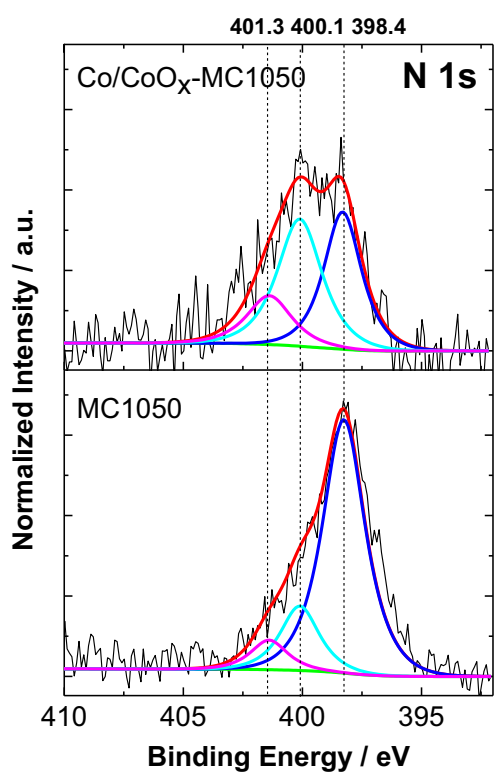

Figure 6. (A) XP Co 2p, (B) O 1s, and (C) N 1s spectra of MC1050 and $\mathrm{Co} / \mathrm{CoO}_{\mathrm{x}} 40-\mathrm{MC} 1050$.

nitrogen decreased while that of pyrrolic nitrogen increased after the microwave treatment process. This indicates that the introduction of transition metals may partially catalyze the decomposition of nitrogen groups upon heating. In our case, it is believed that the cobalt preferentially catalyzes the decomposition of pyridinic nitrogen-contained groups. A similar observation was reported in our previous study for a catalyst containing iron. ${ }^{30}$

\section{Conclusions}

A simple microwave-assisted method for synthesis of a coalderived N-doped carbon matrix (MC) embedding cobalt oxide species $\left(\mathrm{Co} / \mathrm{CoO}_{\mathrm{x}}-\mathrm{MC}\right)$ proved to be versatile and reliable to prepare a very efficient non-precious catalyst for the OER under alkaline conditions. Promising OER activity with overpotentials of $0.370 \mathrm{~V}$ and $0.429 \mathrm{~V}$ at a current density of $1 \mathrm{~mA} \mathrm{~cm}{ }^{-2}$ and $10 \mathrm{~mA} \mathrm{~cm}^{-2}$, respectively, was realized when an optimal amount of cobalt $(40 \mathrm{wt} \%)$ was introduced into coal derived $\mathrm{N}$-doped carbon $\left(\mathrm{Co} / \mathrm{CoO}_{\mathrm{x}} 40-\mathrm{MC} 1050\right)$. This sample also shows good stability without noticeable loss in activity during chronopotentiometric polarization at a constant current density of $10 \mathrm{~mA} \mathrm{~cm}{ }^{-2}$ for a test period of $66 \mathrm{~h}$. Metallic Co and its oxides, $\mathrm{CoO}$ and $\mathrm{Co}_{3} \mathrm{O}_{4}$, were identified in the composite based on TEM, Raman spectroscopy and XPS analysis. The synergistic effect arising from the presence of the heteroatoms present in the pristine coal and the interaction of $\mathrm{Co} / \mathrm{CoO}_{\mathrm{x}}$ with $\mathrm{N}$-doped coal-derived carbon favored enhancement of the OER electrocatalytic performance.

\section{Acknowledgments}

Financial support from National Natural Science Foundation of China (21605067), The Youth Talent Program of University of Science and Technology Liaoning (601011507-06) and The College Creation Competition Program of University of Science and Technology Liaoning (201710146000147) are acknowledged.

\section{ORCID}

\section{References}

1. J. A. Turner, Sustainable hydrogen production, Science, 305, 972 (2004)

2. K. Zeng and D. Zhang, Recent progress in alkaline water electrolysis for hydrogen production and applications, Prog. Energ. Combust. Sci., 36, 307 (2010).

3. Y. Lee, J. Suntivich, K. J. May, E. E. Perry, and Y. Shao-Horn, Synthesis and activities of rutile $\mathrm{IrO}_{2}$ and $\mathrm{RuO}_{2}$ nanoparticles for oxygen evolution in acid and alkaline solutions, J. Phys. Chem. Lett., 3, 399 (2015).

4. X. Sala, I. Romero, M. Rodriguez, L. Escriche, and A. Llobet, Molecular catalysts that oxidize water to dioxygen, Angew. Chem. Int. Ed., 48, 2842 (2010).

5. T. Nakagawa, N. S. Bjorge, and R. W. Murray, Electrogenerated $\operatorname{IrO}_{(x)}$ Nanoparticles as dissolved redox catalysts for water oxidation, J. Am. Chem. Soc., 131, 15578 (2009).

6. S. J. Deng, S. H. Shen, Yu. Zhong, K. L. Zhang, J. B. Wu, X. L. Wang, X. H. Xia, and J. P. Tu, Assembling $\mathrm{Co}_{9} \mathrm{~S}_{8}$ nanoflakes on $\mathrm{Co}_{3} \mathrm{O}_{4}$ nanowires as advanced core/shell electrocatalysts for oxygen evolution reaction, Energ. Chem., 26, 1203 (2017).

7. J. T. Li, G. Q. Du, X. Cheng, P. J. Feng, and X. T. Luo, CoNiP/NC polyhedrons derived from cobalt-based zeolitic imidazolate frameworks as an active electrocatalyst for oxygen evolution, Chinese J. Catal., 39, 982 (2018).

8. A. Chinnappan, D. X. Ji, C. Baskar, X. H. Qin, and S. Ramakrishna, 3-dimensional MWCNT/CuO nanostructures use as an electrochemical catalyst for oxygen evolution reaction, J. Alloy. Compd.,735, 2311 (2017).

9. T. Tian, H. Gao, X. C. Zhou, L. R. Zheng, J. F. Wu, K. Li, and Y. Ding, Study the active sites in porous nickel oxide nanosheets by manganese modulation for enhanced oxygen evolution catalysis, ACS Energ. Lett., 3, 2150 (2018).

10. M. I. Jamesh and X. M. Sun, Recent progress on earth abundant electrocatalysts for oxygen evolution reaction (OER) in alkaline medium to achieve efficient water splitting, J. Power. Sources, 400, 31 (2018).

11. N. Jia, Q. Weng, Y. R. Shi, X. Y. Shi, X. B. Chen, P. Chen, Z. W. An, and Y. Chen, $\mathrm{N}$-doped carbon nanocages: bifunctional electrocatalysts for the oxygen reduction and evolution reactions, Nano Res., 11, 1905 (2018).

12. K. Qu, Y. Zheng, S. Dai, and S. Z. Qiao, Graphene oxide-polydopamine derived N, S-codoped carbon nanosheets as superior bifunctional electrocatalysts for oxygen reduction and evolution, Nano Energ., 19, 373 (2016).

13. Z. Y. Lu, J. Wang, S. F. Huang, Y. L. Hou, Y. G. Li, Y. P. Zhao, S. C. Mu, J. J. Zhang, and Y. F. Zhao, N,B-codoped defect-rich graphitic carbon nanocages as high performance multifunctional electrocatalysts, Nano Energ., 42, 334 (2017).

14. T. Y. Ma, S. Dai, M. Jaroniec, and S. Z. Qiao, Graphitic carbon nitride nanosheetcarbon nanotube three-dimensional porous composites as high-performance oxygen evolution electrocatalysts, Angew. Chem. Int. Ed., 53, 7281 (2014).

15. C. Tang, H. F. Wang, X. Chen, B. Q. Li, T. Z. Hou, B. Zhang, Q. Zhang, M. M. Titirici, and F. Wei, Topological defects in metal-free nanocarbon for oxygen electrocatalysis, Adv. Mater, 28, 6845 (2016).

16. Z. J. Liu, Z. H. Zhao, Y. Y. Wang, S. Dou, D. F. Yan, D. D. Liu, Z. H. Xia, and S. Y. Wang, In situ exfoliated, edge-rich, oxygen-functionalized graphene from carbon fibers for oxygen electrocatalysis, Adv. Mater, 29, 1606207 (2017).

17. Y. Jia, L. Z. Zhang, A. J. Du, G. P. Gao, J. Chen, X. C. Yan, C. L. Brown, and X. D. Yao, Defect graphene as a trifunctional catalyst for electrochemical reactions, Adv. Mater, 28, 9532 (2016).

18. C. Tang, M. M. Titirici, and Q. Zhang, A review of nanocarbons in energy electrocatalysis: multifunctional substrates and highly active sites, J. Energ. Chem., 26, 1077 (2017). 
19. J. S. Qiu, Y. F. Li, Y. P. Wang, and W. Li, Production of carbon nanotubes from coal, Fuel Process. Technol., 85, 1663 (2004).

20. R. Q. Ye, C. S. Xiang, J. Lin, Z. W. Peng, K. W. Huang, Z. Yan, N. P. Cook E. L. G. Samuel, C. C. Hwang, G. D. Ruan, G. Ceriotti, A. R. O. Raji, A. A. Marti, and J. M Tour, Coal as an abundant source of graphene quantum dots, Nat. Commun., 4, 2943 (2013).

21. F. Gao, J. Y. Qu, Z. B. Zhao, Q. Zhou, B. B. Li, and J. S. Qiu, A green strategy for the synthesis of graphene supported $\mathrm{Mn}_{3} \mathrm{O}_{4}$ nanocomposites from graphitized coal and their supercapacitor application, Carbon, 80, 640 (2014).

22. L. X. Kong, J. Bai, H. Z. Li, X. D. Chen, J. Wang, Z. Q. Bai, Z. X. Guo, and W. Li, The mineral evolution during coal washing and its effect on ash fusion characteristics of Shanxi high ash coals, Fuel, 212, 268 (2018).

23. J. W. Kou, Z. Q. Bai, J. Bai, Z. X. Guo, and W. Li, Effects of mineral matter and temperatures on conversion of carboxylic acids and their derivatives during pyrolysis of brown coals, Fuel Process. Technol., 152, 46 (2016).

24. A. Sharma, T. Kyotani, and A. Tomita, A new quantitative approach for microstructural analysis of coal char using HRTEM images, Fuel, 78, 1203 (1999).

25. H. Takagi, K. Maruyama, N. Yoshizawa, Y. Yamada, and Y. Sato, XRD analysis of carbon stacking structure in coal during heat-treatment, Fuel, 83, 2427 (2004).

26. M. Muraoka and M. Nagai, Coals as a novel cathode catalyst for polymer electrolyte fuel cell, Fuel, 94, 204 (2012).

27. M. Muraoka, H. Tominaga, and M. Nagai, Ammonia-treated brown coal and its activity for oxygen reduction reaction in polymer electrolyte fuel Cell, Fuel, 97, 211 (2012).

28. M. Muraoka, H. Tominaga, and M. Nagai, Iron addition to vietnam anthracite coal and its nitrogen doping as a PEFC non-platinum cathode catalyst, Fuel, 102, 359 (2012).

29. S. M. Shamsunnahar and M. Nagai, Nitrogen doping of ash-free coal and effect of ash components on properties and oxygen reduction reaction in fuel cell, Fuel, 126 134 (2014).

30. X. X. Chen, X. N. Huang, T. Wang, S. Barwe, K. P. Xie, Y. U. Kayran, D. Wintrich, W. Schuhmann, and J. Masa, Traditional earth-abundant coal as new energy materials to catalyze the oxygen reduction reaction in alkaline solution, Electrochim. Acta, 211, 568 (2016).

31. X. X. Chen, J. Wang, X. N. Huang, X. F. Zhao, P. G. Liu, B. C. He, T. Wang, and J. Masa, Simple conversion of earth-abundant coal to high-performance bifunctional catalysts for reversible oxygen electrodes, Catal. Sci. Technol., 8, 1104 (2018).

32. Y. Gorlin and T. F. Jaramillo, A bifunctional nonprecious metal catalyst for oxygen reduction and water oxidation, J. Am. Chem. Soc., 132, 13612 (2010).

33. Y. F. Lu, S. T. Lo, J. C. Lin, W. J. Zhang, J. Y. Lu, F. H. Liu, C. M. Tseng, Y. H. Lee, C. T. Liang, and L. J. Li, ACS Nano, 2, 6522 (2013).

34. G. Xu, G. C. Xu, J. J. Ban, L. Zhang, H. Lin, C. L. Qi, Z. P. Sun, and D. Z. Jia, Cobalt and cobalt oxides $\mathrm{N}$-codoped porous carbon derived from metal-organic framework as bifunctional catalyst for oxygen reduction and oxygen evolution reactions, J. Colloid. Interf. Sci., 521, 141 (2018).

35. S. Gupta, A. Yadav, S. Bhartiya, M. K. Singh, A. Miotello, A. Sarkar, and N. Patel, Co oxide nanostructures for electrocatalytic water-oxidation: effect of dimensionality and related properties, Nanoscale, 43, 8806 (2018).

36. S. Asadizadeh, M. Amirnasr, S. Meghdadi, F. F. Tirani, and K. Schenk, Facile synthesis of $\mathrm{Co}_{3} \mathrm{O}_{4}$ nanoparticles from a novel tetranuclear cobalt(III) complex. Application as efficient electrocatalyst for oxygen evolution reaction in alkaline media, Int. J. Hydrogen Energ., 43, 4922 (2018).

37. B. C. He, X. X. Chen, J. M. Lu, S. D. Yao, J. Wei, Q. Zhao, D. S. Jing, X. N. Huang, and $\mathrm{T}$. Wang, One-pot synthesized $\mathrm{Co} / \mathrm{Co}_{3} \mathrm{O}_{4}-\mathrm{N}$-graphene composite as electrocatalyst for oxygen reduction reaction and oxygen Evolution Reaction, Electroanal., 28, 2435 (2016).

38. M. M. Zhu, Y. J. Zhou, Y. Sun, C. Zhu, L. L. Hu, J. Gao, H. Huang, Y. Liu, and Y. H. Kang, Cobalt phosphide/carbon dots composite as an efficient electrocatalyst for oxygen evolution reaction, Dalton T., 47, 5459 (2018).

39. R. C. Li, D. Zhou, J. X. Luo, W. M. Xu, J. W. Li, S. S. Li, P. P. Cheng, and D. S. Yuan, The urchin-like sphere arrays $\mathrm{Co}_{3} \mathrm{O}_{4}$ as a bifunctional catalyst for hydrogen evolution reaction and oxygen evolution reaction, J. Power Sources, 341, 250 (2017).

40. Z. Lu, G. Chen, Y. Li, H. Wang, J. Xie, L. Liao, C. Liu, Y. Liu, T. Wu, Y. Li, A. C. Luntz M. Bajdich, and Y. Cui, Identifying the active surfaces of electrochemically tuned $\mathrm{LiCoO}_{2}$ for oxygen evolution reaction, J. Am. Chem. Soc., 139, 6270 (2017).

41. S. Y. Zhang, T. T. Li, H. L. Zhu, and Y. Q. Zheng, $\mathrm{Co}_{3} \mathrm{O}_{4}$ polyhedrons with enhanced electric conductivity as efficient water oxidation electrocatalysts in alkaline medium, J. Mater. Sci., 53, 4323 (2017).

42. J. Masa, W. Xia, I. Sinev, A. Q. Zhao, Z. Y. Sun, S. Grützke, P. Weide, M. Muhler, and W. Schuhmann, $\mathrm{Mn}_{\mathrm{x}} \mathrm{O}_{\mathrm{y}} / \mathrm{NC}$ and $\mathrm{Co}_{\mathrm{x}} \mathrm{O}_{\mathrm{y}} / \mathrm{NC}$ nanoparticles embedded in a nitrogendoped carbon matrix for high-performance bifunctional oxygen electrodes, Angew. Chem. Int. Ed., 53, 8524 (2014).
43. J. M. Hu, J. Q. Zhang, and C. N. Cao, Oxygen evolution reaction on $\mathrm{IrO}_{2}$-based DSA type electrodes: Kinetics analysis of Tafel lines and EIS, Int. J. Hydrogen Energ., 29, 791 (2004).

44. Z. H. Zhou, W. Q. Zaman, W. Sun, L. M. Cao, M. Tariq, and J. Yang, Cultivating crystal lattice distortion in $\mathrm{IrO}_{2}$ via coupling with $\mathrm{MnO}_{2}$ to boost the oxygen evolution reaction with high intrinsic activity, Chem. Commun., 54, 4959 (2018).

45. K. E. Heusler and E. Gileadi, electrode kinetics for chemists, chemical engineers and material scientists., VCH (1993).

46. J. O. M. Bockris, A. K. N. Reddy, and M. Gamboa-Aldeco, Modern electrochemistry 2A: fundamentals of electrodics., 2nd Ed., Kluwer (2000).

47. A. J. Bard and L. R. Faulkner, Electrochemical methods - fundamentals and applications, 2nd Ed., Wiley (2001).

48. B. M. Jovic, U. C. Lacnjevac, V. D. Jovic, and N. V. Krstaj, Kinetics of the oxygen evolution reaction on NiSn electrodes in alkaline solutions, J. Electroanal. Chem., 754, 100 (2015).

49. A. Kahyarian, B. Brown, and S. Nesic, Mechanism of the hydrogen evolution reaction in mildly acidic environments on gold, Electrochem. Soc., 164, H365 (2017).

50. U. C. Lacnjevac, V. V. Radmilovic, V. R. Radmilovic, and N. V. Krstajic, RuOx nanoparticles deposited on $\mathrm{TiO}_{2}$ nanotube arrays by ion-exchange method as electrocatalysts for the hydrogen evolution reaction in acid solution, Electrochim. Acta, 168, 178 (2015).

51. C. C. L. McCrory, S. Jung, J. C. Peters, and T. F. Jaramillo, Benchmarking heterogeneous electrocatalysts for the oxygen evolution reaction, J. Am. Chem. Soc., 135, 16977 (2013)

52. J. Masa, I. Sinev, H. Mistry, E. Ventosa, M. Mata, J. Arbiol, M. Muhler, B. R. Cuenya, and W. Schuhmann, Ultrathin high surface area nickel boride (NixB) nanosheets as highly efficient electrocatalyst for oxygen evolution, Adv. Energ. Mater., 7, 1700381 (2017).

53. J. Masa, P. Weide, D. Peeters, I. Sinev, W. Xia, Z. Sun, C. Somsen, M. Muhler, and W. Schuhmann, Amorphous cobalt boride $\left(\mathrm{Co}_{2} \mathrm{~B}\right)$ as a highly efficient nonprecious catalyst for electrochemical water splitting: oxygen and hydrogen evolution, $A d v$. Energ. Mater, 6, 1502313 (2016).

54. A. Aijaz, J. Masa, C. Roesler, W. Xia, P. Weide, A. J. R. Botz, R. A. Fischer, W. Schuhmann, and M. Muhler, $\mathrm{Co} @ \mathrm{Co}_{3} \mathrm{O}_{4}$ encapsulated in carbon nanotube-grafted nitrogen-doped carbon polyhedra as an advanced bifunctional oxygen electrode, Angew. Chem. Int. Ed., 55, 4087 (2016).

55. Y. J. Li, J. M. Fan, M. S. Zheng, and Q. F. Dong, A novel synergistic composite with multi-functional effects for high-performance Li-S batteries, Energy. Environ. Sci., 9, 1998 (2016).

56. K. Sato, R. Saito, Y. Oyama, J. Jiang, L. G. Cancado, M. A. Pimenta, A. Jorio, G. G. Samsonidze, G. Dresselhaus, and M. S. Dresselhaus, D-band Raman intensity of graphitic materials as a function of laser energy and crystallite size, Chem. Phys. Lett., 427, 117 (2006)

57. T. Wang, L. X. Wang, D. L. Wu, W. Xia, H. Y. Zhao, and D. Z. Jia, Hydrothermal synthesis of nitrogen-doped graphene hydrogels using amino acids with different acidities as doping agents, J. Mater. Chem., 2, 8352 (2014).

58. A. C. Ferrari, Raman spectroscopy of graphene and graphite: disorder, electronphonon coupling, doping and nonadiabatic effects, Solid State Commun., 143, 47 (2007).

59. M. A. Pimenta, G. Dresselhaus, M. S. Dresselhaus, L. G. Cancado, A. Jorio, and R. Saito, Studying disorder in graphite-based systems by Raman spectroscopy, Chem. Chem. Phys., 9, 1276 (2007).

60. Z. J. Lu, X. X. Chen, P. G. Liu, X. N. Huang, J. Wei, Z. Ren, S. D. Yao, Z. G. Fang, T. Wang, and J. Masa, Co-Mn hybrid oxides supported on N-doped graphene as efficient electrocatalysts for reversible oxygen electrodes, J. Electrochem. Soc., 165, H580 (2018).

61. M. Li, L. Bai, S. J. Wu, X. D. Wen, and J. Q. Guan, Co/CoOx nanoparticles embedded onto carbon for efficient catalysis of oxygen evolution and oxygen reduction reactions, ChemSusChem., 11, 1722 (2018).

62. J. Q. Guan, C. M. Ding, R. T. Chen, B. K. Huang, X. W. Zhang, F. T. Fan, F. X. Zhang, and $\mathrm{C} . \mathrm{Li}, \mathrm{CoO}_{\mathrm{x}}$ nanoparticle anchored on sulfonated-graphite as efficient water oxidation catalyst, Chem. Sci., 8, 6111 (2017).

63. M. Voss, D. Borgmann, and G. Wedler, Characterization of alumina, silica, and titania supported cobalt catalysts, J. Catal., 212, 10 (2002).

64. K. Artyushkova, S. Levendosky, P. Atanassov, and J. Fulghum, XPS structural studies of nano-composite non-platinum electrocatalysts for polymer electrolyte fuel cells, Top. Catal., 46, 263 (2007).

65. S. Kundu, Y. M. Wang, W. Xia, and M. Muhler, Thermal stability and reducibility of oxygen-containing functional groups on multiwalled carbon nanotube surfaces: A quantitative high-resolution XPS and TPD/TPR study, J. Phys. Chem. C, 112, 16869 (2008). 